\title{
Näkökulmia yrittäjyysintentioihin
}

JUSSI PIHKALA

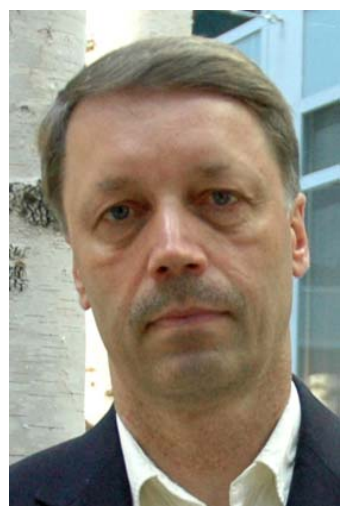

Y

rittäjyys voidaan ymmärtää suppeasti ulkoisena yrittäjyytenä, jolloin se merkitsee pienyrityksen perustamista, omistamista ja johtamista. Laajemmin ymmärrettynä se Kyrön ja Ripatin (2006) mukaan merkitsee myös organisaatioyrittäjyyttä. Organisaatioyrittäjyys viittaa organisaation tai työyhteisön toimintatapaan ja se on luonteeltaan kollektiivinen prosessi. Omaehtoinen yrittäjyys taas liittyy yksilön roolin muuttumiseen. Tällöin merkitykseen liittyy vastuu omasta työllistymisestä, toimeentulosta ja niihin liittyvistä eduista ja riskeistä. Yrittäjyyden laaja käsite toimii koulujärjestelmäämme liittyvän yrittäjyyskasvatuksen taustalla ja se kytkeytyy tällöin myös osallistuvaan ja aktiiviseen kansalaisuuteen.

Yrittäjyyskasvatus sai 1990-luvun alussa laman vuosina sisällöllisesti työvoima- ja elinkeinopoliittisen merkityksen, jonka lähtökohtana oli ensisijaisesti vaikea työllisyystilanne. Koulun tehtävänä nähtiin nuorten kouluttaminen ajattelemaan itsensä työllistymistä ainakin jossakin elämänvaiheessa sen sijaan, että aina hakeudutaan toisen palvelukseen. Nähtiin, että yhteiskunnan pitää tarjota omatoimisen elannon hankintaan tai työmarkkinakelpoisuuden vahvistamiseen liittyvää koulutusta.

Työvoima- ja elinkeinopoliittisen lähestymistavan ohessa yrittäjyyskasvatus sisälsi kuitenkin laajemman kulttuurisen ja yhteiskunnallisen murroksen tavoitteluun liittyvän suuntauksen, missä kohteena on ihmisten ajattelutapoihin liittyvä muu- tos. Yrittäjyys nähtiin siis elämäntapana. Murrosajattelua on kuvattu kansainvälistymisen paineista aiheutuvaksi yksilöiden, organisaatioiden ja valtion uudelleen ryhmittymiseksi. Se ilmenee siirtymisenä staattisuuden ja ennustettavuuden tilasta epävarmuuden ja monimuotoisuuden tilaan. Esimerkkeinä voidaan mainita kysynnän ja tarjonnan mallien muutokset, julkisen ja yksityisen sektorin palvelutuotannon rajapinnan hämärtyminen, työnteon muotojen muuttuminen ja uudelleen organisoituminen. Murrokseen liittyi oleellisesti ammatillisten kompetenssien ja taitojen uudistamistarve. Koulujärjestelmältä odotetaan yrittäjyyden edistämisen osalta paljon. Usko kasvatuksen ja koulutuksen merkitykseen on meilläkin vahva, Suomessa onkin pelkästään tutkintoon johtavan koulutuksen piirissä yli 1,9 miljoonaa yksilöä. Lisäksi yrittäjyys ei näytä olevan synnynnäistä vaan sitä voi oppia.

Yrittäjyyttä tarvitaan, koska meidät on kasvatettu ja koulutettu perinteiseen palkkatyöhön, joka on muuttunut entistä yrittäjämäisemmäksi. Siirtymiset yrittäjän työstä palkkatyöhön ja päinvastoin sekä erilaiset yhdistelmä- ja sekaurat ovat yleistymässä. Työyhteisöjen kehittämisessä korostuvat sisäisen yrittäjyyden opit. Lisäksi työelämässä on tehtäviä ja toimenkuvia, joissa vaikutetaan yrittäjyyden yleisiin edellytyksiin, vaikka itse ei olla omistajayrittäjiä. Yrityksen perustamisen, omistamisen ja johtamisen näkökulmasta toimialarakenteemme on muuttanut muotoaan ja se näyttää synnyttävän jopa uudenlaisia tuotteita ja toimialoja 
sekä antaa mahdollisuuksia uudelle liiketoiminnalle ja uusien yritysten perustamiselle.

Karjalaisen (2008) mukaan korkeakouluilla on neljä päätehtävää yrittäjyyden edistämisessä. Niiden tulee ensinnäkin omalla toiminnallaan edistää myönteistä asennoitumista yrittäjyyteen ja auttaa korkeakouluopiskelijoita näkemään yrittäjyys vaihtoehtona palkkatyölle. Toiseksi niiden tulee turvata yrittäjyyttä suunnitteleville ja yrittäjäksi aikoville riittävät perustiedot ja -taidot. Kolmanneksi korkeakoulujen tulee pyrkiä omassa piirissään syntyneiden ideoiden, tutkimustulosten ja keksintöjen hyödyntämiseen uusien tai olemassa olevien yritysten kautta sekä neljänneksi edistää kasvuyrittäjyyttä.

Tenhusen ja Luopajärven (2007) tutkimuksen mukaan suhtautuminen yrittäjyyteen on ammattikorkeakoulujen opettajien keskuudessa varsin myönteistä. Yrittäjyysstrategian laatiminen on selkeästi johtanut asian tiedostamiseen ammattikorkeakoulujen menestystekijänä. Opettajien omat yrittäjyystiedot ja -taidot ovat heidän oman arvionsa mukaan yli 70 prosentilla tyydyttävällä tai huonolla tasolla. Ikosen (2007) mukaan yrittäjyyden edistämisessä voidaan erottaa kolme päävaihetta. Ensimmäisenä vaiheena on 1950-60-lukujen taloudellisen kasvatuksen kausi, toisena vaiheena 1980-luvun yrittäjäkoulutus ja kolmantena 1990-luvun yrittäjyyskasvatuksen kausi. Yrittäjyyskasvatus ja yrittäjyyskoulutus alkoivat käsitteinä yleistyä. Googlesta löytyy yrittäjyyskasvatuksesta ensimmäinen viittaus vuodelta 1993 ja yrittäjyyskoulutuksesta vuodelta 1997.

\section{Kansainvälisiä ja kansallisia yrittäjyyskasvatuksen linjauksia}

Euroopan unionin komission strategia, työllisyyden suuntaviivat ja tavoitteet painottavat yrittäjyyttä niin uuden työn luojana, urana, osaamisena kuin laajempana kulttuurisena muutosprosessina, johon koulutus kytkeytyy (European Commission's Green paper 2003; European Commission 2005). Taustalla on ajatus siitä, että monimuotoisessa yhteiskunnassa yksilöt tarvitsevat yrittäjämäisiä valmiuksia. Kulttuurinen ja yhteiskunnallinen muutos edellyttää lisäksi laajaa yhteistä näkemystä yrittäjämäisen toiminnan perusteista.

Komission yrittäjyyskasvatusta koskeva tiedonanto (Fostering entrepreneurial mindsets through education and learning 2006) korostaa yrittäjyyden liittämistä osaksi opettajainkoulutusta ja koulutuksen eri tasoja aina korkeakoulutukseen asti. Vuonna 2005 komissio antoi suosituksen elinikäisen oppimisen avaintaidoista. Yrittäjyysosaaminen liitettiin osaksi kyseisiä avaintaitoja. Niitä ovat kommunikointi äidinkielellä ja vierailla kielillä, matemaattiset valmiudet ja perustiedot luonnontieteistä ja teknologiasta, tieto- ja viestintäteknologian perustaidot, oppimaan oppiminen, sosiaaliset ja kansalaistaidot, kulttuurinen tietoisuus ja ilmaisu sekä aloitteellisuus ja yrittäjyys (Recommendation of the European Parliament and of the Council on key competences for lifelong learning 2005).

Yrittäjyys on liitetty eri koulutuksen asteiden opetussuunnitelmien perusteisiin ja koulutusohjelmiin. Koulutuksen ja tutkimuksen kehittämissuunnitelma vuosille 2007-2012 (Opetusministeriö 2007) korostaa yrittäjyyskasvatuksen monipuolistamista ja laajentamista. Hallituksen koulutuspoliittinen selonteko (2006) eduskunnalle nostaa esiin yrittäjyyskasvatuksen ja -koulutuksen merkityksen, samoin Vanhasen toisen hallituksen ohjelma (2007).

\section{Yrittäjyysintentiot teoreettisena viitekehyksenä}

Bridge ym. (1999) kuvaavat erilaisia yrittäjyyden lähestymistapoja. Myötäsyntyistä yrittäjyyttä korostavan koulukunnan näkemyksen mukaan toisilla henkilöillä on jo syntyessään yrittäjyyttä tukeva vaisto, eräänlainen kuudes aisti. Taloustieteen näkökulmasta se merkitsee markkinoiden toimintaan ja tasapainotilanteiden analyysiin perustuvaa reagointia. Psykologian näkökulmasta kysytään, miksi juuri tietyt ihmiset perustavat yrityksiä tai menestyvät yrittäjinä. Tiettyjen persoonallisuuden piirteiden ajatellaan toimivan yrittäjyyden taustalla, esimerkiksi taipumus riskinottoon, kontrollikäsitys (locus of control) ja suoriutumistarve (need for achievement). Sosiologian näkökulmasta yrittäjyyttä lähestytään demografisilla tekijöillä, joita ovat koti- ja perhetausta, sukupuoli ja kokemustausta. Yrittäjyyteen työntävinä tekijöinä pidetään ainakin työttömyyttä tai sen uhkaa, työviihtyvyyttä, palkkausta ja tyytymättömyyttä johtamiseen. Yrittäjyyteen vetävinä tekijöinä taas pidetään halua itsenäisyyteen ja riippumattomuuteen, itsensä toteuttamisen halua, oman osaamisen tai keksinnön hyödyntämistä ja muita markkinoiden tarjoamia myönteisiä mahdollisuuksia. 
Lähtökohtana tutkimuksessani on inhimillisen toiminnan tietoiseen ja tavoitteelliseen toimintaan liittyvä pohdinta, jonka alkujuuret juontavat kreikkalaisiin filosofeihin ja jota pohdintaa myöhemmin harrasti 1940-luvun lopusta erityisesti Ludwig von Mises (1981;1996) tuoden prakseologian käsitteen vastapainoksi vallalla olleelle positivistiselle suuntaukselle.

Yksilön inhimilliseen toimintaan ja tarkoitushakuisuuteen liittyvä keskustelu näyttää kirjallisuuden valossa olevan niukkaa kymmenien vuosien ajan Misesin jälkeen. Uudelleen tuleminen tapahtui 1970-luvulla, jolloin inhimillistä käyttäytymistä koskevaan keskusteluun tuli Misesin ajatuksia suoraviivaisempi intention käsite ja se kohdentui yksilön päätekäyttäytymistä edeltävään vaiheeseen. Tuolloin Fishbein ja Ajzen (1975) näkivät intention muodostavan liittymäkohdan yksilön uskomusten ja niistä aiheutuvan käyttäytymisen välille. Bagozzille (1992) taas asenteet eivät olleet riittäviä intentioiden selittäjiä eikä intentiot riittävän toiminnan yllykkeitä, vaan hän painotti myös tiedollisuuden ja emotionaalisuuden merkitystä. Intentioissa on siis kyse käyttäytymisen aikomuksellisuudesta ja niitä pidetään hyvänä käyttäytymisen ennustajana. Ne ovat osoituksia siitä, kuinka kovasti yksilö on halukas ponnistelemaan toteuttaakseen tietyn käyttäytymisen. Esimerkiksi intentio ryhtyä yrittäjäksi syntyy, jos haluttu tavoite näyttää riittävän houkuttelevalta sen vaatimiin ponnistuksiin ja uhrauksiin nähden.

Yrittäjyysintentioista käydyn keskustelun pohjalta tutkimuksen viitekehys muodostui oheisen kuvion mukaiseksi. Opiskelijan sukupuoli sekä aikaisempi kosketus yrittäjyyteen nostettiin taustatekijöiksi. Ajzenin (1991) teorian hahmottama uskomusten kokonaisuus muodostivat viitekehyksen yhden elementin. Boydin ja Vozikis’n (1994) malliinsa integroima omiin kykyihin luottamuksen elementti oli myös oleellinen sen tuodessa dynaamisuuden ulottuvuuden intentioprosessiin. Krueger ym. (2000) osaltaan laajensi intentioajattelua mahdollisuuksien syntymisen ja havaintojen näkökulmista liittämällä malliinsa nopeuttavien tekijöiden (precipitating factors) ulottuvuuden. Tämä ulottuvuus yrittäjyysintentiomallin osana on tärkeä koulujärjestelmän näkökulmasta, koska opinnoissa voidaan tuoda esiin yrittäjyydelle myönteisiä roolimalleja, mutta myös kouluttaa opiskelijaa arvioimaan omakohtaisia, yritystoiminnan käynnistämisen kannalta keskeisiä inhimillisiä ja aineellisia resursseja ja niiden riittävyyttä. Pihkalan (1998) tutkimus osoitti, että korkeakouluopiskelijat eivät olleet kohdanneet myönteisiä yrittäjän roolimalleja, kielteisiä kylläkin.

\section{Tutkimuksen viitekehys}

\section{Tutkimusstrategia ja -menetelmät sekä tutkimuksen suorittaminen}

Tutkimukseni on lähtökohdaltaan monistrateginen. Menetelminä ovat kvantitatiivinen surveytutkimus ja kvalitatiivinen fokusryhmähaastattelu. Siinä tavoitellaan fenomenologista lähestymistapaa, kvantitatiivisessa osuudessa on kuitenkin

\section{Tutkimuksen viitekehys}

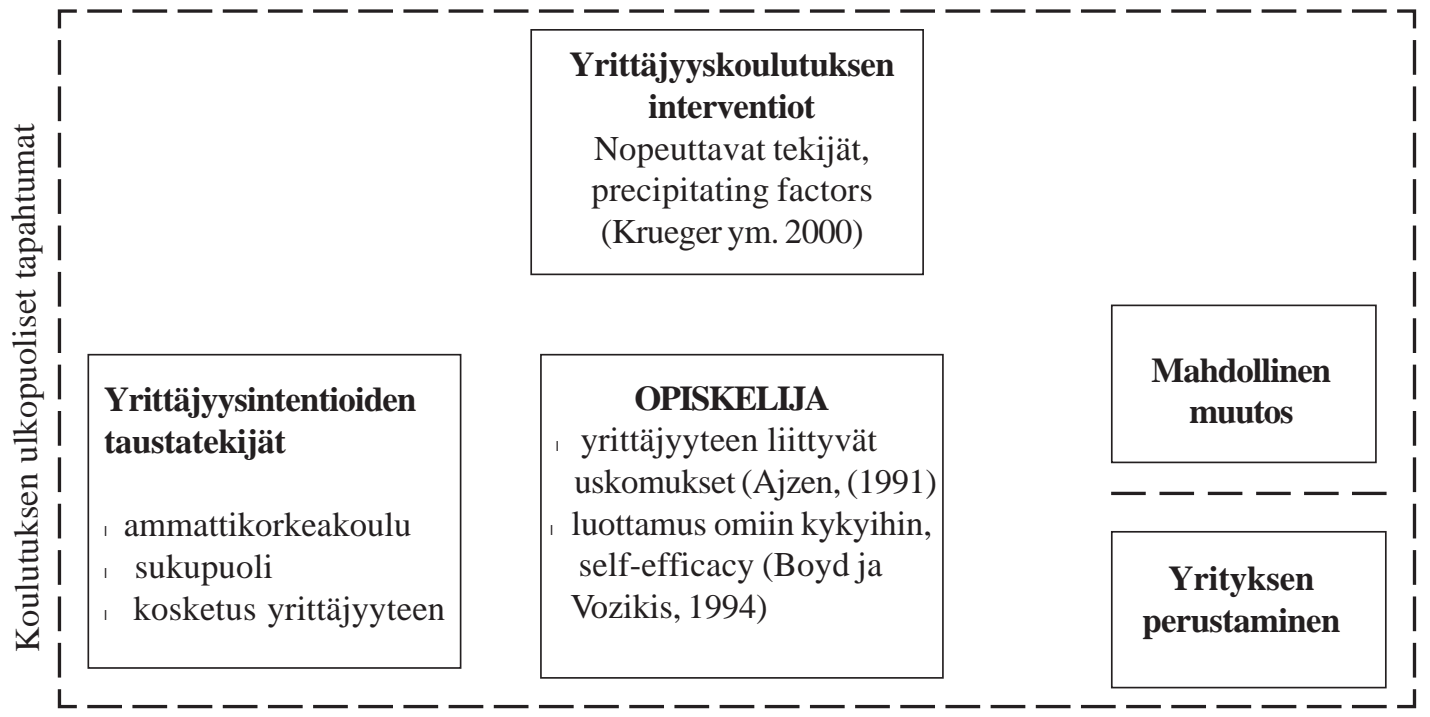


havaittavissa uuspositivistista ulottuvuutta. Tutkimuksen pääongelma on, muuttavatko ammattikorkeakoulun yrittäjyysopinnot opiskelijoiden yrittäjyysintentioita. Tutkimuksen kiinnostava kysymys on, miten ammattikorkeakoulut onnistuvat yrittäjyyskoulutuksessaan muutoksen aikaansaamiseksi.

Tutkimukseen liittyvä aineisto kerättiin ajallisesti kahdessa eri vaiheessa. Tein syksyllä 2000 postikyselyn opintonsa aloittaneille opiskelijoille. Vastanneita opiskelijoita oli 177. Heille toistettiin sama kysely vuosien 2003-2004 vaihteessa, jolloin vastanneita oli 91. Tällöin toteutin myös viidestä eri koulutusohjelmasta yhteensä 18 opiskelijan fokusryhmähaastattelun. Kato oli siis huomattava johtuen siitä, että opiskelijoista huomattava osa vaihtoi ammattikorkeakoulun sisällä koulutusohjelmaa tai siirtyi toiseen ammattikorkeakouluun tai yliopistoon.

Tutkin kvantitatiivisen aineiston avulla yrittäjyysintentioiden muutosta ja kvalitatiivisen aineiston avulla sen luonnetta. Ammattikorkeakouluista valitsin kaksi yrittäjyysstrategialtaan erilaista kokonaisotosta viidestä eri koulutusohjelmasta. Koulutusohjelmapainotukset olivat yrittäjyyden näkökulmasta ammattikorkeakoulujen välillä erilaiset.

\section{Tulokset}

Tulosten mukaan opiskelijat kokevat yrittäjyyskoulutuksen merkityksen osana opintoja tärkeänä. Kaikille kohdennettu yrittäjyyskoulutus on tärkeää sen tuodessa yleistä tietoa ja ymmärrystä yrittäjyydestä. Yrittäjyyskoulutus nähdään myös keinoksi tavoittaa potentiaaliset yrittäjyydestä kiinnostuneet opiskelijat. Yrittäjyyskoulutuksen avulla yrittäjien määrää ei opiskelijoiden mielestä saada lisättyä. Opintojen aikaiset yritys- ja yrittäjäkontaktit eivät vaikuta opiskelijoiden mielestä heidän omiin yrittäjyysaikomuksiinsa. Ne aiheuttavat kuitenkin myönteistä suhtautumista toimiviin yrittäjiin ja yritystoiminnan kansantaloudelliseen merkitykseen liittyvän ymmärryksen lisääntymistä.

Opiskelijat korostavat yrittäjyysopintojen nykyistä parempaa konkretiaa, niiden vahvempaa kytkemistä omaan ammattialaan sekä yrittäjyysopintojen oikeata jaksottamista ja ajoittamista koko opintojen keston ajalle. Heidän mukaansa yrittäjyyden edistämiseksi opinnoissa on syytä kiinnittää nykyistä enemmän huomiota opiskelijan itsearvioinnin tukemiseen, omien kykyjen ja vahvuuksien tunnistamiseen. Yrityskontaktien määrän li- säämisen sijasta korostetaan niiden laadun kehittämistä. Kannustavimpina yrittäjäesimerkkeinä pidetään oman ikäisiä ja samassa vaiheessa opintoja olevia tai samasta oppilaitoksesta valmistuneita yrittäjänuoria, samoin oman oppilaitoksen yritystoimintaa harjoittavia opettajia. Koulussa tietoa yrittäjyydestä ennen ammattikorkeakouluopintoja oli saanut vain vajaa puolet opiskelijoista.

\section{Pohdinta}

Ajzenin (1991) teorian mukainen uskomusten kokonaisuus, Boydin ja Vozikis'n (1994) omiin kykyihin luottamisen elementti ja Kruegerin ym. (2000) nopeuttavien tekijöiden rooli viitekehyksen osina oli tutkimuksessani onnistunut ratkaisu. Asenteiden lisäksi on syytä kuitenkin pohtia myös sitä, mitä Bagozzin (1992) näkemys tiedollisuuden ja emotionaalisuuden merkityksestä intentioiden ja niiden muutoksen selittäjinä olisi tuonut lisää viitekehykseen. Muutoksen voidaan ajatella liittyvän opiskelijan taitojen, tietojen, käsitteiden, valmiuksien ja asenteiden rakenteisiin, jotka liittyvät opiskelijan toimintaan, käyttäytymiseen ja valintoihin. En kuitenkaan tutkinut kyseisiä rakenteellisia muutoksia, vaan muutoksen suuntaa ja tasoa kokonaisuutena. Bagozzin (1992) näkökulma voisi siihen osaltaan antaa pohjaa

Intentioita on tärkeää ymmärtää nykyistä enemmän. Kruegerin ja Carsrudin (1993) mukaan kouluttajat ja yrittäjyyttä opettavat henkilöt hyötyvät intentioiden muodostumiseen liittyvästä tiedosta. Yrittäjyyden realiteettien oppiminen voi lisätä opiskelijoiden luottamusta omiin kykyihin ja samalla vahvistaa yritystoiminnan käynnistämisen haluttavuutta. Intentiomallien ymmärtäminen luo pohjan opiskelijoiden motivaation tunnistamiselle, yrittäjyyskoulutuksen suunnittelulle ja toimeenpanolle. Intentiomalleja voidaan soveltaa myös yrityksissä strategisen päätöksenteon yhteydessä, esimerkiksi liiketoiminnan laajentamiseen ja yrityksen kasvuun liittyen.

Intentiomalleihin ei juurikaan kytketä yksilön persoonallisuutta ja piirteitä, enkä sitä tee myöskään omassa tutkimuksessani. 2000-luvulla näyttää kuitenkin syntyneen tutkimusta, jossa niitä liitetään osaksi intentimalleja, esimerkiksi Luethe ja Franke (2003) integroivat yrittäjyysintentiomalliinsa kaksi persoonallisuuden piirrettä, taipumuksen riskinottoon (risk taking propensity) ja kontrollikäsityksen (locus of control) sekä kontekstuaaliset tekijät. 
Tutkimukseni tulosten kannalta on mielenkiintoista pohtia myös sitä, miten vahvistaa luottamusta omiin yrittäjyyskykyihin. Tieto näyttää lisäävän tuskaa. Opiskelijat arvioivat yrittäjyyskoulutuksen tuovan epävarmuutta omiin yrittäjyyskykyihin luottamisessa johtuen asetetuista yrittäjyysopintojen ylimitoitetuista tavoitteista, yrittäjäksi kannustamisen ja siihen liittyvän henkisen tuen puutteesta sekä yrittäjyysopintojen laadusta ja niiden ajoituksesta. Opiskelijat tarvitsevat opintojensa tueksi laadukasta koulutuksen ja elinkeinoelämän yhteistyötä, opintojen konkretiaa, huomiota itsearviointiin ja palautetta omista vahvuuksista ja heikkouksista sekä nuoria yrittäjyyden roolimalleja. Tutkimuksen tulosten valossa on syytä pohtia sitä, missä määrin opiskelijoiden yrittäjäksi ryhtymisen asenteisiin voidaan vaikuttaa ammattikorkeakoulutasolla ja minkälaisten koulutusjärjestelyjen avulla. Nuorisobarometrin (2004) mukaan yrittäjyyshalut huipentuvat noin 25-vuotiaana ja yrittäjyyden lisäämiseen tähtäävien toimenpiteiden tulisi kohdentua juuri tähän ikään ja sitä nuorempiin. Kyseisen ikävaiheen jälkeen yrittäjyyshalukkuus näyttää laskevan melko nopeasti. Toisaalta tilastot osoittavat, että eniten yrityksiä perustavat 35-vuotiaat. Yrittäjyyskasvatuksen laajan määritelmän ja koulutusjärjestelmälle asetettujen yrittäjyyskasvatuksen tavoitteiden näkökulmasta tärkeä tulos on se, että opiskelijoille syntyy tietoisuus ja näkemystä yritystoiminnan merkityksestä osana yhteiskuntaa ja kansantaloutta, vaikka itse ei yrittäjäksi ryhdytä.

On kehitettävä toimintamalleja- ja tapoja, joiden avulla opiskelijat voidaan jalkauttaa enemmän yrityksiin ja kontaktiin yrittäjien luo sen sijaan, että yrittäjiä ja yritysten edustajia toivotaan oppilaitoksiin. Koulutusohjelmien suunnittelun ja toteutuksen kannalta näyttääkin tärkeältä ottaa huomioon useita seikkoja. Yrittäjyysopintojen järjestelyjä ja sisältöjä pitää harkita tarkemmin, opinnot pitää jaksottaa mielekkäämmin opintojen lomaan, käytännönläheisesti ja opiskelijan omaan alaan kytkettynä. Yrittäjyyttä tukevien oppimisympäristöjen kehittäminen näyttää nousevan tärkeäksi alueeksi, kun haluamme opiskelijoiden luottavan nykyistä enemmän yrittäjyskykyihinsä. Niiden kehittämiseen liittyvät ainakin teorian ja käytännön yhteyden tiivistäminen, toiminnallisuuden ja kokemuksellisuuden korostuminen, koulutusorganisaatioiden, työ- ja elinkeinoelämän laadukas yhteistyö, johtajuus sekä opettajien perus- ja täydennyskoulutus. Valmisteilla oleva opettajien täy- dennyskoulutusvelvoite antanee tähän myös mahdollisuuksia.

Euroopan unionin komission (2008) suositusten mukaisesti tarvitsemme korkeakouluille muiden muassa työ- ja elinkeinoelämän sekä yliopistojen yhteistyötä tukevan lainsäädännön, yrittäjyysstrategiat ja yrittäjyyden johdantokurssit kaikille opiskelijoille. Hyviin tuloksiin korkeakoulu yltääkin, kun sillä on selkeä strateginen tavoitteenasettelu ja suunnitelma yrittäjyyden edistämiseen. Yliopistoistamme 4-5 on laatinut yrittäjyysstrategiansa. Korkeakoulujen osalta toteutettiin juuri eräitä yrittäjyyttä tukevia uudistuksia. Lainsäädäntöä selkiytettiin korkeakoulukeksintöihin liittyvien oikeuksien osalta vuoden 2007 alusta ja samaan aikaan yliopistojen taloudellista itsehallintoa lisättiin. Tutkimustulosten hyödyntämistä varten tarvitaan riittävät välittäjäorganisaatiopalvelut. Ammattikorkeakouluilla on yhteinen yrittäjyysstrategia (ARENE 2006). Sen mukaan joka seitsemäs ammattikorkeakoulusta valmistunut on aloittanut yrittäjäuran 10 vuoden kuluessa tutkinnon suorittamisesta vuonna 2010. Tulosten valossa näyttää isolta haasteelta saavuttaa ammattikorkeakoulujen yhteisen yrittäjyysstrategian (ARENE 2006) tavoite.

Jatkotutkimuksen kannalta tarvitsemme laajaa ja useita korkeakouluja ja koulutusohjelmia koskevaa pitkittäistutkimusta. Lisäksi olisi aiheellista seurata yrittäjyysintentioiden mahdollista laukeamista yritystoiminnaksi useampaa vuotta myöhemmin koulutuksen jälkeen. Koulutuksen sisältöjen, niiden ajoittamisen sekä menetelmien parempi suunnittelu edellyttäisi yrittäjyyttä ja yrittäjämäistä toimintaa tukevien oppimisen prosessien sekä pedagogiikan tutkimusta. Olisi syytä myös tutkia, miksi opiskelijoiden luottamus omiin yrittäjyyskykyihin vaihtelee huomattavasti. Tutkimukseni kohdentui 2000-luvun ensimmäisille vuosille. Sen jälkeen yrittäjyyskoulutuksen laatu monimuotoisten uusien koulutuksen järjestelyjen ja menetelmien kautta näyttää huomattavasti kehittyneen.

\section{Lähteet}

Bagozzi, R. P. (1992). The Self-Regulation of Attitudes, Intentions and Behavior. Social Psychology Quarterly 10 (2), 178-204.

Boyd, N. G., \& Vozikis, G. S. (1994). The Influence of Self-efficacy on the Development of Entrepreneurial Intentions and Actions. Entrepreneurship Theory and Practice , 18 (4), 63-77. 
Cox, L. W., Mueller, S. L., \& Moss, S. E. (2002). The Impact of Entrepreneurship Education on Entrepreneurial Self-Efficacy. International Journal of Entrepreneurship Education, 1 (1), 229-245.

European Commission's Green paper 2003. Yrittäjyyden vihreä kirja (2003). Euroopan unionin komissio.

Fishbein, M., \& Ajzen, I. (1975). Belief, Attitude, Intention and Behavior: An Introduction to Theory and Research. USA: Addison-Wesley Publishing Company.

Fostering entrepreneurial mindsets through education and learning (2006). Communication from the Commission to the Council, the European Parliament, the European Economic and Social Committee and Committee of the Regions. Implementing the Community Lisbon Programme: Commission of the European Communities. Brussels.

Hallituksen koulutuspoliittinen selonteko eduskunnalle 2006. OPM 2006:24.

Krueger, Jr. N. F., \& Carsrud, A. L. (1993). Entrepreneurial intentions: Applying the theory of planned behaviour. Entrepreneurship \& Regional Development, 5, 315-330.

Krueger, N. F., Reilly, M. D., \& Carsrud, A. L. (2000). Competing Models of Entrepreneurial Intentions. Journal of Business Venturing, 15 (5/6), 411-432.
Mises von Ludwig (1996). Human Action: A Treatise On Economics. Neljäs painos 1996, painettu 1998. NY. Irvington-on-Hudson,

Mises von Ludwig (1981). The Theory of Money and Credit. 1912. Kolmas painos 1981. Indianapolis: Liberty Fund.

Nuorisobarometri 2004. Oman elämänsä yrittäjät? Wilska T-A (toim.) Nuorisoasiain neuvottelukunta, julkaisuja 28. Nuorisotutkimusverkosto/Nuorisotutkimusseura, julkaisuja 44. Opetusministeriö. Helsinki. Edita.

Opetusministeriö 2007. Koulutus ja tutkimus 2007-2012. Kehittämissuunnitelma. Opetusministeriön julkaisuja 2007. Yliopistopaino.

\section{Internet-lähteet}

ARENE, 2006. Yrittäjyysstrategia.

http://www.arene.fi

Commission of the European Communities 2003. Recommendation of the European Parliament and of the Council on key competences for lifelong learning

http://europa.eu/scadplus/leg/en/cha/c11090.htm

Vanhasen toisen hallituksen ohjelma

http://www.valtioneuvosto.fi/hallitus/hallitusohjelma/pdf/hallitusohjelma-painoversio-040507.pdf 